\title{
Front Matter: Volume 10764
}

, "Front Matter: Volume 10764," Proc. SPIE 10764, Earth Observing Systems XXIII, 1076401 (12 November 2018); doi: 10.1117/12.2515129

SPIE Event: SPIE Optical Engineering + Applications, 2018, San Diego, California, SPIE. United States 


\section{PROCEEDINGS OF SPIE}

\section{Earth Observing Systems XXIII}

James J. Butler

Xiaoxiong (Jack) Xiong

Xingfa Gu

Editors

21-23 August 2018

San Diego, California, United States

Sponsored and Published by

SPIE 
The papers in this volume were part of the technical conference cited on the cover and title page. Papers were selected and subject to review by the editors and conference program committee. Some conference presentations may not be available for publication. Additional papers and presentation recordings may be available online in the SPIE Digital Library at SPIEDigitalLibrary.org.

The papers reflect the work and thoughts of the authors and are published herein as submitted. The publisher is not responsible for the validity of the information or for any outcomes resulting from reliance thereon.

Please use the following format to cite material from these proceedings:

Author(s), "Title of Paper," in Earth Observing Systems XXIII, edited by James J. Butler, Xiaoxiong (Jack) Xiong, Xingfa Gu, Proceedings of SPIE Vol. 10764 (SPIE, Bellingham, WA, 2018) Seven-digit Article CID Number.

ISSN: 0277-786X

ISSN: 1996-756X (electronic)

ISBN: 9781510620995

ISBN: 9781510621008 (electronic)

Published by

SPIE

P.O. Box 10, Bellingham, Washington 98227-0010 USA

Telephone +1 3606763290 (Pacific Time) · Fax +1 3606471445

SPIE.org

Copyright (C) 2018, Society of Photo-Optical Instrumentation Engineers.

Copying of material in this book for internal or personal use, or for the internal or personal use of specific clients, beyond the fair use provisions granted by the U.S. Copyright Law is authorized by SPIE subject to payment of copying fees. The Transactional Reporting Service base fee for this volume is $\$ 18.00$ per article (or portion thereof), which should be paid directly to the Copyright Clearance Center (CCC), 222 Rosewood Drive, Danvers, MA 01923. Payment may also be made electronically through CCC Online at copyright.com. Other copying for republication, resale, advertising or promotion, or any form of systematic or multiple reproduction of any material in this book is prohibited except with permission in writing from the publisher. The CCC fee code is 0277$786 \mathrm{X} / 18 / \$ 18.00$.

Printed in the United States of America.

Publication of record for individual papers is online in the SPIE Digital Library.

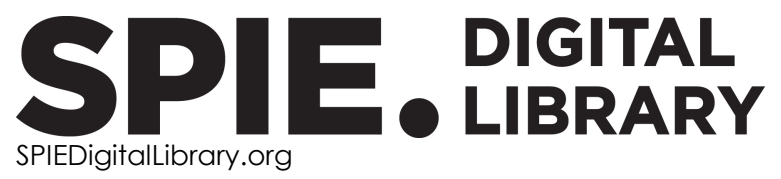

Paper Numbering: Proceedings of SPIE follow an e-First publication model. A unique citation identifier (CID) number is assigned to each article at the time of publication. Utilization of CIDs allows articles to be fully citable as soon as they are published online, and connects the same identifier to all online and print versions of the publication. SPIE uses a seven-digit CID article numbering system structured as follows:

- The first five digits correspond to the SPIE volume number.

- The last two digits indicate publication order within the volume using a Base 36 numbering system employing both numerals and letters. These two-number sets start with $00,01,02,03,04$, 05, 06, 07, 08, 09, 0A, OB ... 0Z, followed by 10-1Z, 20-2Z, etc. The CID Number appears on each page of the manuscript. 


\title{
Contents
}

\author{
ix Authors \\ xi Conference Committee
}

\section{PRELAUNCH CALIBRATION}

1076403 Prelaunch characterization and performance of JPSS-2 VIIRS reflective solar bands [10764-1]

1076404 JPSS-1 VIIRS solar diffuser witness sample BRF calibration using a table-top goniometer at NASA GSFC [10764-2]

1076405 Spectral testing of the Landsat-9 OLI-2 instrument using the Goddard Laser Absolute Measurement of Radiance (GLAMR) [10764-3]

1076406 Landsat 9 Thermal Infrared Sensor 2 pre-launch characterization: initial imaging and spectral performance results [10764-4]

1076407 Characterizations of a KHz pulsed laser detection system [10764-5]

\section{NEW INSTRUMENTS AND TECHNOLOGIES}

$1076409 \quad$ Electro-optical sensors for Earth observation missions [10764-7]

10764 OA UAV-based remote sensing for NaTech accidents management [10764-9]

10764 OB Prism spectrometer analysis for field use [10764-10]

10764 OC Hawkeye radiometric calibration methodology [10764-11]

GOES-16I

10764 OD Characterization of GOES-16 ABI detector-level uniformity from post-launch north south scan collections of several earth targets [10764-12]

10764 OE In-orbit response versus scan-angle (RVS) validation for the GOES-16 ABI solar reflective bands [10764-13]

10764 OF Validation of GOES-16 ABI infrared spatial response uniformity [10764-14] 
10764 OG GOES-16 ABI navigation assessment [10764-15]

GOES-16 II

$10764 \mathrm{OH} \quad$ Independent validation of the advanced baseline imager (ABI) on NOAA's GOES-16: postlaunch ABI airborne science field campaign results [10764-16]

$10764 \mathrm{OI} \quad$ Validation of GOES-16 ABI reflective solar band calibration through reanalysis and comparison with field campaign data [10764-17]

$10764 \mathrm{OJ}$ On-orbit validation of the geolocation accuracy of GOES-16 Geostationary Lightning Mapper (GLM) flashes using ground-based laser beacons [10764-18]

\section{NEW MISSIONS}

10764 OK An update on EUMETSAT programmes and plans [10764-20]

$10764 \mathrm{OL}$ The 3MI mission on-board EPS-SG: a multi-spectral multi-polarization multi-directional imager for operational characterization of aerosol and cloud [10764-21]

10764 OM A new approach of remote sensing satellite programs in Taiwan [10764-22]

AIRS

10764 ON Reducing uncertainty in the AIRS radiometric calibration [10764-23]

$1076400 \quad$ Radiometric stability in 16 years of AIRS hyperspectral infrared data [10764-24]

10764 OP Stratified radiometric means for the evaluation of AIRS and CrIS [10764-25]

\section{CERES}

10764 OR Early trends on the Clouds and the Earth's Radiant Energy System (CERES) Flight Model 6 (FM6) instrument's performance [10764-27]

10764 OT Radiometric calibration discrepancy and root cause analysis for radiation budget instrument [10764-29] 
ON-ORBIT, VICARIOUS, AND INTER-INSTRUMENT CALIBRATION

10764 OU NOAA-20 VIIRS on-orbit calibration and characterization using the Moon [10764-30]

10764 OV MODIS and VIIRS on-orbit calibration and characterization using observations from spacecraft pitch maneuvers [10764-31]

10764 OW Evaluation of early NOAA-20 VIIRS RSB radiometric performance using intercomparison with Aqua MODIS [10764-32]

10764 OX Suomi NPP VIIRS DNB and RSB M bands detector-to-detector and HAM side calibration differences assessment using a homogenous ground target [10764-63]

10764 OY SBAF for cross-calibration of Landsat-8 OLI and Sentinel-2 MSI over North African PICS [10764-34]

10764 OZ Directional reflectance studies in support of the Radiometric Calibration Test Site (RadCaTS) at Railroad Valley [10764-35]

\section{MODIS}

1076411 MODIS cross-talk effects and areas of potential performance differences for Terra from Aqua characteristics [10764-37]

1076412 Assessment of the on-orbit MODIS SRCA spectral uncertainty [10764-38]

1076413 Effects of time-varying relative spectral response on the calibration of MODIS reflective solar bands [10764-39]

1076414 MODIS solar diffuser degradation determination and its spectral dependency [10764-40]

\section{DATA ANALYSIS AND ALGORITHMS}

1076415 On the effectiveness of remote monitoring systems [10764-41]

1076416 Change detection for high resolution image based on pyramid mean shift smoothness and morphology [10764-42]

$1076417 \quad$ Hyperspectral image denoising using improved low-rank and sparsity constraints [10764-43]

1076418 Enhancements to the open access spectral band adjustment factor online calculation tool for visible channels [10764-44] 
VIIRS I

10764 1A SNPP VIIRS reflective solar bands on-orbit calibration six-year update: extension and improvements [10764-45]

10764 1B Initial on-orbit radiometric calibration of the NOAA-20 VIIRS Reflective Solar Bands [10764-46]

10764 IC NOAA-20 VIIRS reflective solar bands on-orbit calibration using solar diffuser and solar diffuser stability monitor [10764-47]

10764 ID On-orbit RSB calibration of SNPP VIIRS using the full illumination profile of solar diffuser [10764-48]

VIIRS II

10764 IF Analysis of S-NPP VIIRS RSB bands detector saturation status and its change with time [10764-50]

$107641 \mathrm{H} \quad$ JPSS-1/NOAA-20 VIIRS early on-orbit geometric performance [10764-52]

$1076411 \quad$ A light contamination ranking index-based method for automating VIIRS day/night band stray light correction [10764-53]

$10764 \mathrm{lJ} \quad$ An improved algorithm for VIIRS Day/Night Band (DNB) high gain stage (HGS) dark offset determination [10764-54]

\section{POSTER SESSION}

$107641 \mathrm{~L} \quad$ Ring laser in angle measurements [10764-56]

$107641 \mathrm{M} \quad$ Identification of seismic signals at the output of large ring laser gyroscope [10764-57]

10764 IN Detection and characterization of striping in GOES-16 ABI VNIR/IR bands [10764-58]

1076410 On-orbit performance of the Terra and Aqua MODIS solar diffuser stability monitor [10764-59]

10764 IP Methods of Earth-view-based calibration of the response versus scan angle of the MODIS reflective solar bands [10764-60]

$107641 Q \quad$ NOAA-20 VIIRS radiometric band saturation evaluation and comparison with Suomi NPP VIIRS using global probability distribution function method [10764-61]

10764 IT Radiometric quality assessment of GOES-16 ABI L1b images [10764-65]

$107641 \mathrm{U}$ Orbital variations and impacts on observations from SNPP, NOAA 18-20, and AQUA sunsynchronous satellites [10764-66] 
10764 IV Comparison of the MODIS and VIIRS on-board SD and SDSM performance [10764-67]

$10764 \mathrm{lW}$ Object detection in multispectral and panchromatic image using superpixel segmentation and multisource feature [10764-68]

10764 1X Saliency and density enhanced region-of-interest extraction for large-scale high-resolution remote sensing images [10764-69]

$107641 Y \quad$ A land-cover classification method of high-resolution remote sensing imagery based on convolution neural network [10764-71]

1076412 A building edge extraction method based on dual-scale classification with decision fusion for satellite image [10764-72]

$1076420 \quad$ Optical multi-spectral strip filter by lithography and ion beam assisted deposition for multispectral remote sensing instrument [10764-73] 
Proc. of SPIE Vol. 10764 1076401-8

Downloaded From: https://www.spiedigitallibrary.org/conference-proceedings-of-spie on 26 Apr 2023 Terms of Use: https://www.spiedigitallibrary.org/terms-of-use 


\section{Authors}

Numbers in the index correspond to the last two digits of the seven-digit citation identifier (CID) article numbering system used in Proceedings of SPIE. The first five digits reflect the volume number. Base 36 numbering is employed for the last two digits and indicates the order of articles within the volume. Numbers start with 00, 01, 02, 03, 04, 05, 06, 07, 08, 09, OA, OB...0Z, followed by 10-1Z, 20-2Z, etc.

\author{
Abdelatif, Adam, OB \\ Aldoretta, Emily J., 12, 10 \\ Anderson, Nikolaus J., OB, $\mathrm{OZ}$ \\ Angal, Amit, 03, OV, 13, 10, 1P, 1V \\ Armstrong, Peter, 0J \\ Aumann, Hartmut H., ON, OO, OP \\ Barbieri Vita, Linda, OA \\ Barsi, Julia A., 05 \\ Bartlett, Brent, OD, OH, OI \\ Bhatt, Rajendra, 18 \\ Blonski, Slawormir, 1B, $1 \mathrm{~J}$ \\ Bremer, James, 0J \\ Broberg, Steven E., ON, 00 \\ Buechler, Dennis, 0J \\ Butler, James J., 04, 07, 0V \\ Cao, Changyong, OD, OH, OI, 1B, $11,1 \mathrm{~J}, 1 \mathrm{Q}, 1 \mathrm{U}$ \\ Cao, Zhimin, $1 \mathrm{Z}$ \\ Casey, Jason, OD, OH, OI \\ Chee, Thad, 18 \\ Chen, Chia-Ray, OM \\ Chen, Hongda, 10, 1P \\ Chen, Xuexia, OX, $1 \mathrm{~F}$ \\ Chiang, Kwofu, OV, IF \\ Choi, Taeyoung, OI, 1B \\ Chu, Mike, OW, ID \\ Ciucci, Mariano, OA \\ Coburn, Craig A., $\mathrm{OZ}$ \\ Cook, Monica, OD \\ Cooper, John W., 07 \\ Czapla-Myers, Jeffrey S., OB, OZ \\ Dellomo, John J., 0G, $1 \mathrm{H}$ \\ Ding, Leibo, 07 \\ Doelling, David R., 18 \\ Efremova, Boryana, 06 \\ Eno, N. Abraham, 1L, 1M \\ Fan, Xintong, $1 Y$ \\ Feldman, Gene, OC \\ Filatov, Yuri V., $1 \mathrm{~L}$ \\ Fougnie, Bertrand, OL \\ Fulbright, Jon, OJ \\ Geng, XU, IP \\ Georgiev, Georgi T., OT \\ Goodman, Steve, 0J \\ Gopalan, Arun, 18 \\ Gravelle, Chad, OF \\ Gu, Lingjia, $1 Y$ \\ Gu, Yalong, $1 \mathrm{~J}$ \\ Guenther, B., 11 \\ Gunshor, Mathew, OF
}

Guo, Qingle, 16, 17, 1W, 1X, 12

Hair, Jason, 06

Haney, Conor, 18

Hao, Lechuan, $1 \mathrm{Z}$

Hasan, Nahid, OY

Helder, Dennis, OY

Hernandez, Oscar, OB

Hertel, Richard, OT

Holmes, Alan, OC

Huang, Chien-Fu, 20

Huang, Po-Hsuan, 20

lacovazzi, Robert, OF, 1N, $1 \mathrm{~T}$

Ji, Qiang, 03

Johnston, Shaida, 05

Kahn, Brian H., OP

Kelley, Nathan, 04

Klaes, K. Dieter, OK

Kondratovich, Vladimir, OF, IT

Lacan, Antoine, $\mathrm{OL}$

Lalanne, Elaine N., 07

Lamb, Rivers, OJ

Lang, Ruediger, $\mathrm{OL}$

Lee, Hyung R., OT

Lee, Shihyan, 0C, 14

Lei, Ning, OX, 1F, IV

Leigh, Larry, OY

Li, Tong, $1 \mathrm{X}$

Lin, Guoqing, $1 \mathrm{H}$

Lindsey, Dan, OF

Link, Daniel, 12

Liu, Tung-Chang, $11,1 \mathrm{U}$

Lunsford, Allen, 06

Manning, Evan M., ON, 0O, OP

Marbach, Thierry, OL

Marino, Alessandra, OA

Markham, Brian, 05

McAndrew, Brendan, 05

McCorkel, Joel, 05, 06

McIntire, Jeff, 03

Meister, Gerhard, 0C, 14

Mkrtchyan, F. A., 15

Moeller, Christopher, 11

Montanaro, Matthew, 06

Morris, D., 09

Moyer, David, 03

Munro, Rosemary, OL

Oudrari, Hassan, 03

Padula, Francis, OD, OH, Ol

Pagano, Thomas S., ON 
Patt, Frederick S., OC

Pavlov, P. A., 1L

Pearlman, Aaron, 06, OD, OH, Ol

Piccirilli, Chiara, OA

Pogorzala, Dave, OD, $\mathrm{OH}$

Poli, Gabriele, OL

Predina, Joe, OT

Priestley, Kory J., OR, OT

Qian, Haifeng, OE, OF, OI, IN, $1 \mathrm{~T}$

Ramirez, Michael, OF

Randall, Christopher R., OT

Ren, Ruizhi, $1 Y$

Reth, Alan, $0 \mathrm{G}$

Reuter, Dennis, 06

Scarino, Benjamin, 18

Schluessel, Peter, OL

Schmit, Tim, OF

Shankar, Mohan, OT

Shao, Xi, OE, OF, OI, 1I, 1N, 1Q, 1T, IU

Shrestha, Mahesh, OY

Shuman, Timothy, 05

Simon, Amy, 06

Smith, Nathaniel P., OR

Strow, Larrabee, ON

Sun, Chengbo, if

Sun, Junqiang, OU, OW, 11, 1A, 1C, 1D

Swindells, I., 09

Szewczyk, Z. Peter, OR

Tan, Bin, OG, $1 \mathrm{H}$

Tari, J. B., $1 \mathrm{M}$

Teixeira Pinto, Cibele, OY

Thomas, Susan, OR

Thome, Kurtis J., $\mathrm{OZ}$

Tilton, James $C_{\text {., }} 1 \mathrm{H}$

Twedt, Kevin A., 12, 13, 10, 1P, 1V

Uprety, Sirish, OI, 1I, 1 J, 1Q, 1U

Van Naarden, John, OF

Varghese, Thomas, OJ

Wang, Menghua, OU, OW, 1A, 1C, ID

Wang, Wenhui, 11

Wang, Yuhan, $1 Y$

Wang, Zhipeng, OF, 1N, IT

Weiler, Margie, $\mathrm{ON}$

Wenny, Brian N., 06, OZ

Williams, Yana Z., OT

Wilson, Robert, OR

Wolfe, Robert E., OG, $1 \mathrm{H}$

Woody, Loren, OT

Wu, Aisheng, OV, $1 \mathrm{P}$

Wu, Di, $1 \mathrm{~W}$

Wu, Xiangqian, OE, OF, OI, $1 \mathrm{~N}, 1 \mathrm{~T}$

Xiong, Xiaoxiong, 03, 04, OV, OX, 12, 13, 1F, 10,

$1 \mathrm{P}, 1 \mathrm{U}, 1 \mathrm{~V}$

Yoo, Hyelim, OF, 1N, $1 \mathrm{~T}$

Young, Cindy L, OT

Yu, Fangfang, OE, OF, OI, $1 \mathrm{~N}, 1 \mathrm{~T}$

Zeng, Jinan, 04, 07

Zhang, Bin, $1 \mathrm{l}, 1 \mathrm{~J}, 1 \mathrm{Q}, 1 \mathrm{U}$

Zhang, Junping, 16, 17, 1X

Zhang, Ping, $1 \mathrm{H}$
Zhang, Ye, 16, 1W, $1 \mathrm{Z}$

Zheng, $\mathrm{XU}, 1 \mathrm{Y}$

Zhong, Chongxiao, 17

Zou, Bin, 1X

Zukowski, Barbara, 05 


\title{
Conference Committee
}

\author{
Program Chair
}

Allen H.-L. Huang, University of Wisconsin-Madison (United States)

Conference Chairs

James J. Butler, NASA Goddard Space Flight Center (United States)

Xiaoxiong (Jack) Xiong, NASA Goddard Space Flight Center

(United States)

Xingfa Gu, Institute of Remote Sensing Applications (China)

Conference Program Committee

Philip E. Ardanuy, Innovim, LLC (United States)

Jeffrey S. Czapla-Myers, College of Optical Sciences, The University of Arizona (United States)

Armin Doerry, Sandia National Laboratories (United States)

Christopher N. Durell, Labsphere, Inc. (United States)

Bertrand Fougnie, EUMETSAT (Germany)

Dennis L. Helder, South Dakota State University (United States)

Joel McCorkel, NASA Goddard Space Flight Center (United States)

Vijay Murgai, Raytheon Space and Airborne Systems (United States)

Thomas S. Pagano, Jet Propulsion Laboratory (United States)

Jeffery J. Puschell, Raytheon Space \& Airborne Systems

(United States)

Mark A. Schwarz, SAIC (United States)

Session Chairs

1 Prelaunch Calibration

Christopher N. Durell, Labsphere, Inc. (United States)

2 New Instruments and Technologies

Bertrand Fougnie, EUMETSAT (Germany)

3 GOES-16।

Xiaoxiong (Jack) Xiong, NASA Goddard Space Flight Center (United States)

4 GOES-16 II

James J. Butler, NASA Goddard Space Flight Center (United States) 
5 New Missions

Xiaoxiong (Jack) Xiong, NASA Goddard Space Flight Center (United States)

6 AIRS

Armin W. Doerry, Sandia National Labs. (United States)

7 CERES

Xiaoxiong (Jack) Xiong, NASA Goddard Space Flight Center (United States)

8 On-Orbit, Vicarious, and Inter-Instrument Calibration

James J. Butler, NASA Goddard Space Flight Center (United States)

9 MODIS

Jeffrey S. Czapla-Myers, College of Optical Sciences, The University of Arizona (United States)

10 Data Analysis and Algorithms

Amit Angal, Science Systems and Applications, Inc. (United States)

11 VIIRS I

Thomas S. Pagano, Jet Propulsion Laboratory (United States)

12 VIIRS II

Joel McCorkel, NASA Goddard Space Flight Center (United States) 